\title{
A NEW APPROACH OF EGYPTIAN CALCIUM CARBONATE UTILIZATION AS INGREDIENTS OF TOOTHPASTE MANUFACTURE
}

\author{
Gaber, M. A. ${ }^{1}$ and Gaber, M. A. ${ }^{2}$ \\ 1-Egyptian Petroleum Research Institute, Exploration Department, Nasr City, Cairo, Egypt \\ (mgaber01@hotmail.com) \\ 2-Al-Azhar University, Faculty of Science (boys), Botany and Microbiology Department, Cairo, Egypt
}

\begin{abstract}
Nowadays, the calcium carbonate material is used on a wide scale as an effective dietary calcium supplement, antacid, phosphate binder, and base material for medicine tablets such as baking powder and toothpaste components. This study introduces a contribution and characterization of the Beni Khaled calcium carbonate for toothpaste pharmaceutical ingredients. Calcium carbonate samples were ground to very fine grain size ranging from $5-20$ um to be used as an abrasive ingredient of toothpaste components by $25-55 \%$ as per international standard. The testing techniques include measuring of physical, chemical and biological properties; XRF, XRD, water absorption, matter soluble in water, and biological study of harmful bacteria types which disappeared with the heating of $\mathrm{CaCO}_{3}$ powder up to $121^{\circ} \mathrm{C}$.
\end{abstract}

Keywords: Calcium Carbonate; pharmaceutical filler; Minia; toothpaste; biological properties.

\section{INTRODUCTION}

The main ingredients of toothpaste composed of abrasive and binders. The most ore mineral used in toothpaste abrasives are (1) Ground calcium carbonates (GCC) and precipitated calcium carbonates (PCC) with a ratio of up to $55 \%$. The size of $\mathrm{CaCO}_{3}$ utilized in different kinds of toothpaste varies from 0.7 to 10 um. (2)Silica is composed of quartz or silicon dioxide. (3) Mica used as a mild abrasive to give the polishing of the tooth appearance. (4) Titanium is a hard silvery-white metallic element that is found in the ilmenite minerals. Each abrasive also has slightly different cleaning properties, and a combination of them might be used in the final product as per Burnet et al. (2006).

In the present study the main target to assess the calcium carbonate properties to be utilized in toothpaste as abrasive ingredients. This study carries out the exploration of high-quality chalk and limestone from open cast mines and chooses the samples with a high content $\left(>90 \% \mathrm{CaCO}_{3}\right)$ and about $95 \%$ whiteness at Beni Khaled area according to Gaber (2013). The large grain size introduced for crushing to obtain a small size, and then to the processing plant for more crushing by using jaw or cone crusher up to $4 \mathrm{~cm}$, and finally more process of grinding to produce a very fine $\mathrm{CaCO} 3$ powder with 10 um size.

\section{MATERIALS AND METHODS}

Twenty calcium carbonate samples were collected from Beni Khalid "Minia". It is located between latitudes $28^{\circ}$ and $28^{\circ} 40^{\prime} \mathrm{N}$ and longitudes $30^{\circ} 50^{\prime}$ and $31^{\circ} 30^{\prime} \mathrm{E}$. The exposed calcium carbonate rock of Minia - Maghagha areas include five units of Middle Eocene age and composed mainly of calcium carbonate as per Abdel Tawab (1994) \& Abu El Ghar et al. (2005). The collected samples were ground to very fine grain size ranging from $5-20 \mathrm{um}$ to determine the physical, chemical, and biological properties (Fig.1-b).

The assessment of ground calcium carbonate characterizations was conducted as per Indian standard 918 (2006), and the following quality control testing of GCC "Physical properties, XRD and XRF, and biological testing Counts" was conducted as follows: 
Gaber, M. A. and Gaber, M. A.

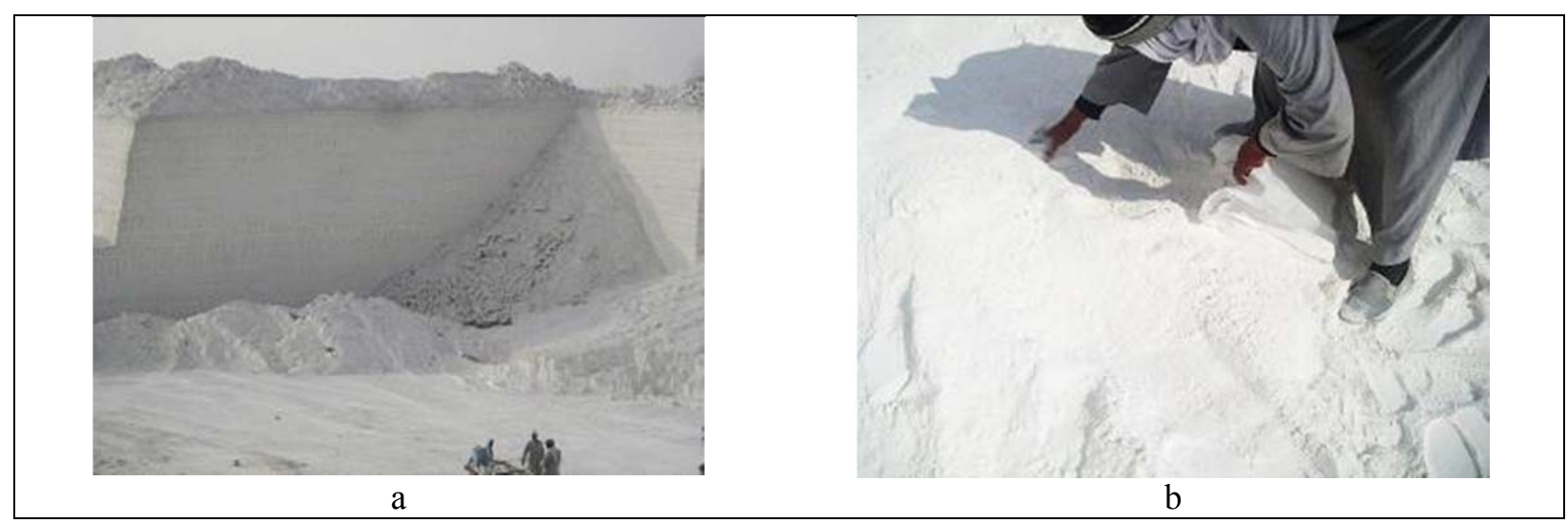

Fig. 1: Field photos for a quarry of pure limestone at El Minia, East Nile Valley, (a) Large limestone outcrop (b) Calcium carbonate powder (5-20um

\section{Microbial isolation}

\section{Bacterial isolation}

By using $1 \mathrm{gm}$ of each $\mathrm{CaCO}_{3}$ sample was merged in $9 \mathrm{ml}$ of sterilized saline solution, shacked for about $5 \mathrm{~min}$. and serial dilution was made. Different types of enrichment and selective media were used as follows; Plate count agar media (PCA) as per Atlas (2004), Nutrient agar media as per Atlas (1993) \& Cowan (1993), Mannitol salt agar media (MSA) as per Idziak and Mossel (1980) and Blood agar media as per Reddy et al. (2007).

\section{Fungal isolation}

The Isolation was carried out as follows; Malt extracts agar media as per Gutz and Doe (1973).

\section{Bacterial identification}

\section{Morphological studies}

Morphological characters of all pure bacterial colonies including, pattern, color, and arrangement on the agar plates, were recorded.

\section{Staining methods}

a- Simple stain was prepared and stained according to Curry et al. (1993), using methylene blue and crystal violet.

b- Gram-stains were prepared using a modification of Gram stain as per Hucker (1927).

c- Catalase property was tested for the obtained species as per Benson (2001).

\section{Fungal Identification}

Fungal genera and/or species were identified morphologically on the plate agar media and by microscopic examination.

\section{Sterilization of the $\mathrm{CaCO}_{3}$ samples}

It was sterilized by wet sterilization using Autoclave at two levels of temperature as follows:

\section{Autoclaving at $110^{\circ} \mathrm{C}$ for $15 \mathrm{~min}$}

One gram of each $\mathrm{CaCO}_{3}$ samples was merged in $9 \mathrm{ml}$ of sterilized saline solution, shacked for about 5 min. and serial dilution was made and placed in autoclave adjusted at $110^{\circ} \mathrm{C}$ for $15 \mathrm{~min}$. After sterilization, all the above media were inoculated from the serial dilutions, incubation for each media at $110^{\circ} \mathrm{C}$ and 15 minutes then the resultswere recorded. 
A new approach of Egyptian calcium carbonate utilization

\section{Autoclaving at $121^{\circ} \mathrm{C}$ for 15 min.}

One gram of each $\mathrm{CaCO} 3$ sample was merged in $9 \mathrm{ml}$ of sterilized saline solution shacked for about 5 min. and serial dilution was carried out and placed in an autoclave that adjusted at $121^{\circ} \mathrm{C}$ for $15 \mathrm{~min}$. Different types of enrichment and selective media were inoculated from the serial dilutions and incubations were conducted at $121^{\circ} \mathrm{C}$ for 15 minutes.

\section{RESULTS AND DISCUSSION}

The methodology included the agar diffusion technique that has been used as a regular method of checking the antibacterial sensitivity. Although this method is convenient for fluid materials like water, it's been also used for antimicrobial assessment of semi-solid matters which are fluid in the presence of saliva or water such as toothpaste.

Toothpaste (dentifrice) is important for daily oral hygiene routine. The most target of toothpaste to improves the mechanical brushing and cleaning of teeth. The function of oral hygiene using toothpaste is to cut back oral bacterial flora and deliver fluoride to the teeth. The fluoride plays a crucial role to shield teeth against attack of bacteria, it helps remove plaque, prevent decay by strengthening enamel, found naturally in many everyday things including food and water. The carbonate within the Pharmaceutical industry is employed as an abrasive ingredient of toothpaste and cosmetic industry and structure to $55 \%$ as per Kiruthiga (2011).

The physic-chemical analyses were conducted to assessment the Egyptian pure calcium carbonate located in Mina area as follows:

Physical properties were accomplished for Beni Khaled calcium carbonate powder as follows: Loss on drying: Weigh $5 \mathrm{~g}$ of the fabric in a very weighed, clean and dry squat form weighing bottle, and dry to constant weight at $105^{\circ} \mathrm{C} \pm 22^{\prime} \mathrm{C}$.

Loss on drying, per cent by mass $=100 \times \mathrm{W}_{\mathrm{I}} / \mathrm{W}_{2}$

Where; $\mathrm{W} 1 \mathrm{wt}$. of sample before heating and $\mathrm{W}_{2} \mathrm{wt}$. of sample after heating to $105^{\circ} \mathrm{C}$ )

The results of calcium carbonate powder loss on drying is ranging from $0.05-0.07$, these values comply with the desired parameter as indicated in Table (1), and thought of low percentage and good property for toothpaste as per American Standard for Testing Material - D 280 (1987).

Specific gravity: The studied samples of calcium carbonate were measured as per American Standard for Testing Material D- 153 (1989), and the results are $2.65 \mathrm{~g} / \mathrm{cm}^{3}$ as shown in Table (1).

Table 1: Physical and chemical properties of studied calcium carbonate

\begin{tabular}{|l|l|l|l|}
\hline Physical Properties & Result & Chemical Properties & Result \\
\hline Whiteness & $96 \%$ & $\mathrm{CaO}$ & $55.65 \%$ \\
\hline Water Absorption & 40 to $50 \mathrm{ml} / 100 \mathrm{gm}$ & $\mathrm{MgO}$ & $0.10 \%$ \\
\hline Oil Absorption & 30 to $32 \mathrm{ml} / 100 \mathrm{gm}$ & L.O.I & $43.75 \%$ \\
\hline Loss on Drying at $105^{\circ} \mathrm{C}$ & $0.05-0.07 \%$ & Iron as Fe & $0.11 \mathrm{ppm}$ \\
\hline Specific Gravity & $2.65 \mathrm{~g} / \mathrm{cm}^{3}$ & Matter insoluble in HCL & $1 \%$ \\
\hline Moisture $\%$ & 0.05 to 0.07 & $\mathrm{pH}$ & 8.5 \\
\hline Hardness (Moh's) & 3 & Phosphate & $150 \mathrm{ppm}$ \\
\hline Matter soluble in water & $0.75 \%$ & Chloride as $\mathrm{Cl}$ & $0.18 \mathrm{ppm}$ \\
\hline Acid soluble & $99 \%$ & & \\
\hline Average Particle Size & 5 to $20 \mu \mathrm{m}$ & & \\
\hline
\end{tabular}

Matter soluble in water: The carbonate powder shall be insoluble in water as per American Standard for Testing Material D- 2198 (1989), except some traces of soluble salt. The result of studied samples of soluble matter is $0.75 \%$ as indicated in the Table (1),

Oil absorption: Administrated by using linseed oil which mixed with $\mathrm{CaCO}_{3}$ powder up to obtain the paste as per American Standard for Testing Material D- 234 (1991) and American Standard for Testing 
Gaber, M. A. and Gaber, M. A.

Material D-281 (1989), and then a quantity of oil was measured and located in the range of 30 to 32 $\mathrm{g} / 100 \mathrm{~g}$.

Particle size "Fineness": The studied samples were ground to small size about 10 um using ball mill (Fig. 2). The particle size curve show that the studied samples are ranging from 5- 20 um as illustrated in (Fig. 3 ), whereas the $80 \%$ of the studied sample is smaller than 20 um grain size.

Whiteness (5GE): The $\mathrm{CaCO}_{3}$ was examined by using Dr Lange's equipment, and also the results verify the degree of whiteness value $96 \%$ as mentioned in Table (1).

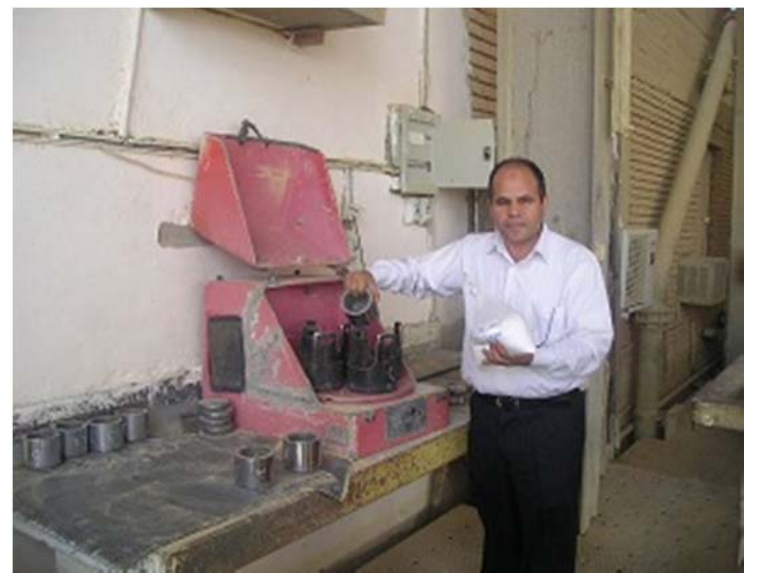

Fig.2. Ball mill for grinding of limestone

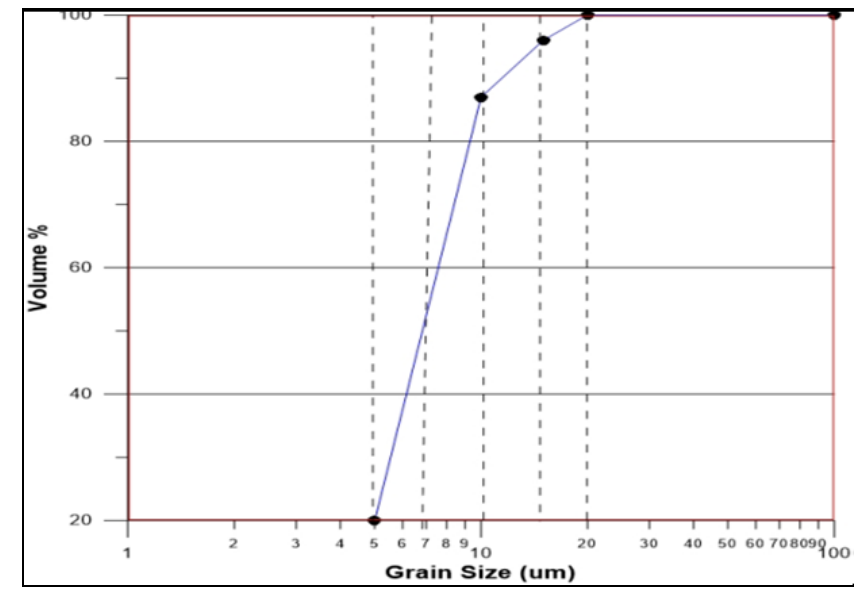

Fig. 3. $\mathrm{CaCO}_{3}$ powder grain size (5-20 um)

\section{Chemical analysis}

- X-Ray Diffraction: The carbonate per cent within the examined samples are starting from 99.30 to 99.55 $\%$, which classified as high purity carbonate as per Harrison (1992).

- XRD of representative samples from Beni Khaled showing that the calcite mineral is the dominant mineral in carbonate rocks with a mean ratio of $99.55 \%$ as illustrated in (Fig.4).

- X-Ray Florescence: It's administrated to 4 samples reflects that the most elements is $\mathrm{CaO} 55.65$; which implies that the ratio of $\mathrm{CaCO}_{3}$ is 99.55 , which comply with the specification of $\mathrm{CaCO}_{3}$ required for toothpaste. These results indicate that the studied sample possesses high purity and suitable for toothpaste manufacture.

- $p H$ value: The hydrogen ion concentration test was completed for the collected sample as per American Standard for Testing Material - E 70 (1990), to work out the worth of alkaline or acidity of $\mathrm{CaCO}_{3}$ powder and also the results of $\mathrm{pH}$ gives 8.5 as illustrated in Table (1).

Fig. 4: XRD of Limestone at Beni Khaled area.

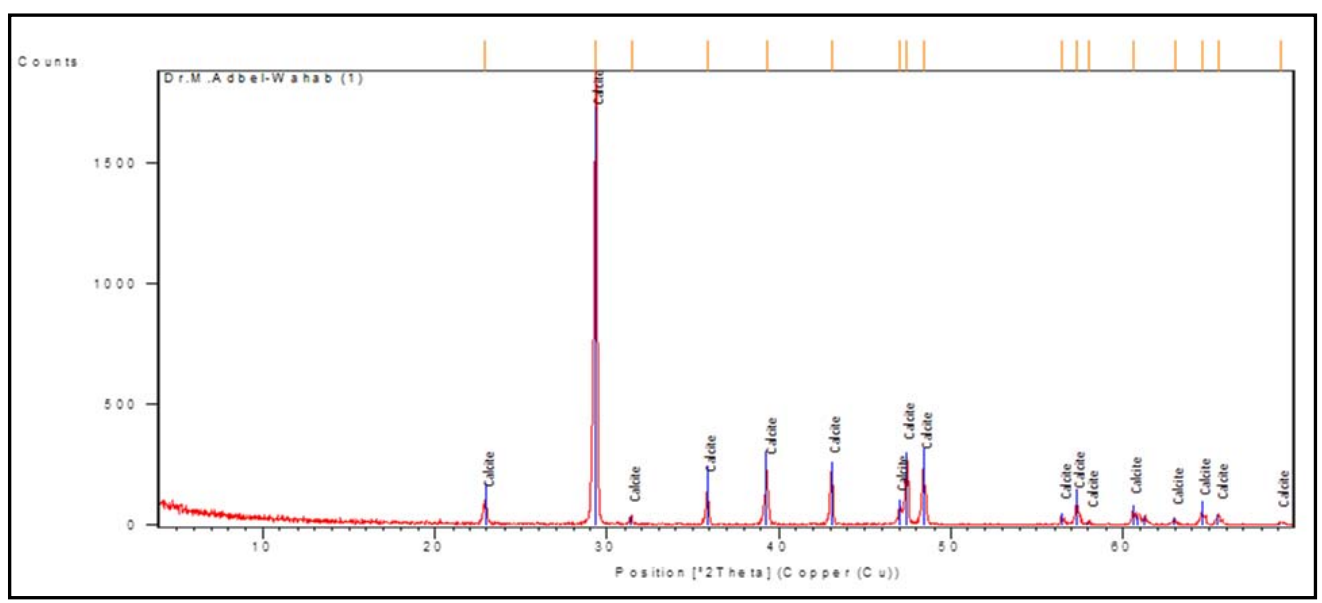


A new approach of Egyptian calcium carbonate utilization

\section{Biological testing}

\section{Isolation and identification of bacteria from calcium carbonate}

This test was completed to isolate and identify the various bacterial species that occurred within the different carbonate samples. Different types of enrichment and selective media were used for counting and isolation of bacterial species that occurred within the carbonate of the Beni Khaled area. The results indicate that $1 \mathrm{gm}$ from each carbonate sample contains two types of bacterial species as recorded within the Table $(2 \& 3)$.

Table 2: Characters of different bacterial Genera and /or Species found in the studied $\mathrm{CaCO}_{3}$ sample 1

\begin{tabular}{|l|l|l|}
\hline Test & \multicolumn{2}{|c|}{ Result } \\
\hline & \multicolumn{1}{|c|}{ Species (1) } & Species (2) \\
\hline Plate count agar media & $22 \times 10^{6}$ & $4 \times 10^{6}$. \\
\hline Nutrient agar media & Small colonies with yellow color. & $\begin{array}{l}\text { Large colonies with white } \\
\text { color. }\end{array}$ \\
\hline Mannitol salt agar media & Growth with yellow color zone & -ve \\
\hline Blood agar media & $\beta$ - heamolysis & $\gamma$-heamolysis \\
\hline Simple stain & Staphylococci shape & Streptobacilli shape \\
\hline Gram stain & $+\mathrm{ve}$ & - -ve \\
\hline Catalase activity & $+\mathrm{ve}$ & $+\mathrm{ve}$ \\
\hline
\end{tabular}

Table 3: Characters of different bacterial Genera and /or Species found in the studied $\mathrm{CaCO}_{3}$ of sample 2

\begin{tabular}{|l|l|l|}
\hline Test & \multicolumn{2}{|c|}{ Result } \\
\hline Plate count agar media & \multicolumn{1}{|c|}{ Species (1) } & Species (2) \\
\hline Nutrient agar media & $13 \times 10^{6}$. & $45 \times 10^{6}$. \\
\hline Mannitol salt agar media & Small colonies with yellow color. & $\begin{array}{l}\text { Large and yellow } \\
\text { colonies. }\end{array}$ \\
\hline Blood agar media & $\begin{array}{l}\text { Growth with yellow color around the } \\
\text { colonies }\end{array}$ & -ve \\
\hline Simple stain & $\beta$ - heamolysis & $\gamma$-heamolysis \\
\hline Gram stain & Staphylococci shape & streptobacilli shape \\
\hline Catalase activity & + ve & - ve \\
\hline
\end{tabular}

\section{Isolation and identification of fungal species of studied carbonate}

Malt extract agar media were used for the isolation of various fungal species that occurred in samples. From the morphological and microscopic examination, Table (4) shows three differing kinds of Fungi observed in carbonate sample 1; white with black spots Rhizopus 1x104, yellow Penicillium 2x104, and white Aspergillus 4x 104. Table (5) indicates the presence of 4 kinds of fungi in carbonate 2; yellow Penicillium 3x 104, white Aspergillus 3x 104, deep yellow Aspergillus 2x 104, grey Aspergillus 4x 104.

Table.4: Characters of fungal Genera found in the studied calcium carbonate sample 1

\begin{tabular}{|l|l|l|l|}
\hline \multicolumn{2}{|c|}{ Three different types of fungi were observed } \\
\hline & Color & Total No. & Microscopic examination \\
\hline Species (1) & White with some black parts & $1 \times 10^{4}$ & Rhizopus shape \\
\hline Species (2) & Yellow & $2 \times 10^{4}$ & Penicillium shape \\
\hline Species (3) & White & $4 \times 10^{4}$ & Aspergillus shape \\
\hline
\end{tabular}

The results illustrated within the Table (6) shows the odds of microorganism types detected within the $\mathrm{CaCO}_{3}$ sample 1 is Streptobacillus with $22-84 \%$, Staphylococcus with $15-74 \%$. In $\mathrm{CaCO}_{3}$ sample 2 the microorganism found Penicillium with $25-28 \%$, Aspergillus with $57-75 \%$, Rhizopus with the percentage starting from 0 to $14 \%$. 
Gaber, M. A. and Gaber, M. A.

Table 5: Characters of fungal Genera and /or Species found in the studied calcium carbonate of sample 2

\begin{tabular}{|l|l|l|l|}
\hline \multicolumn{5}{|l|}{ Four different types of fungi were observed } & $3 \times 10^{4}$ & Penicillium shape \\
\hline Species (1) & Yellow & $3 \times 10^{4}$ & Aspergillus shape \\
\hline Species (2) & White & $2 \times 10^{4}$ & Aspergillus shape \\
\hline Species (3) & Deep yellow & $4 \times 10^{4}$ & Aspergillus shape \\
\hline Species (4) & Gray
\end{tabular}

Table 6: Relative percentages of different microorganism types detected in the studied $\mathrm{CaCO}_{3}$

\begin{tabular}{|c|c|}
\hline \multicolumn{2}{|c|}{ Types of bacterial species in sample 1} \\
\hline Species & Percentage (\%) \\
\hline Streptobacillus & $22-84 \%$ \\
\hline Staphylococcus & $15-77 \%$ \\
\hline \multicolumn{2}{|c|}{ Types of fungal species in sample 2} \\
\hline Species & Percentage (\%) \\
\hline Penicillium & $25-28 \%$ \\
\hline Aspergillus & $57-75 \%$ \\
\hline Rhizopus & $0-14 \%$ \\
\hline
\end{tabular}

\section{Sterilization of the studied calcium carbonate}

\section{Autoclaving at $110{ }^{\circ} \mathrm{C}$ for 15 min}

On plate count, agar media $\left(9 \times 10^{4}\right)$ and $\left(4 \times 10^{2}\right)$ of Streptobacilli species were found in $1 \mathrm{gm}$ from sample1 and $1 \mathrm{gm}$ of sample 2, respectively, while all other microorganisms were killed. There is no growth of microorganisms was observed on mannitol salt agar media or blood agar media. This indicates that the Staphylococcus and Fungal species were killed at $110^{\circ} \mathrm{C}$ and 15 minutes of sterilization.

\section{Autoclaving at $121{ }^{\circ} \mathrm{C}$ for 15 min:}

The Calcium carbonate powder of Beni Khaled area sterilization carried out on $121^{\circ} \mathrm{C}$ for $15 \mathrm{~min}$, and then the observation indicates that is no growth of bacterial or fungal species on any type of enrichment and selective media, this result confirms the killing of all microorganisms. The study recommends sterilizing the calcium carbonate at $110^{\circ} \mathrm{C}$ for 15 minutes before using in pharmaceutical or medical industries to ensure there are no hazardous microorganisms.

\section{CONCLUSIONS}

This study indicates the following positive conclusions:

1- Biological study at ambient temperature indicates the presence of some microorganisms.

2- Biological study and sterilization at $121^{\circ} \mathrm{C}$ and 15 minutes show no presence of harmful microorganisms and can be used safely in producing pharmaceutical products.

3- Cooperation of the geologists and pharmacists to find the Egyptian substitute ores instead of imported ones and safe hard currency.

4-The presence of a lot of reserve of $\mathrm{CaCO}_{3}$ in the Beni Khaled area can be mined by an open cast and located near infrastructure road and El Mina industrial area.

5- XRD analysis indicates that the Calcium carbonate samples have a high content of $\mathrm{CaCO}_{3}$ "99.55\%" suitable for the pharmaceutical industry.

Conflict of Interest: The authors have declared no conflict of interest. 
A new approach of Egyptian calcium carbonate utilization

\section{REFERENCES}

Abdel Tawab, S. (1994): A Geotechnical Evaluation of Minia-Maghagha Area, Upper Egypt; Earth Sciences Journal, ISSN 1012-8832, 7, 143-157.

Abu El Ghar, M. S., and Hussein, A. W., (2005): Post-depositional changes of the lower-middle Eocene limestone of the area between Assiut and Minia, west of the Nile valley, Egypt, first international conference on the geology of the Tethys, Cairo University.

Atlas, R. M., (2004): Handbook of Microbiological Media. London: CRC Press. 1390. ISBN 0-8493$\underline{1818-1 .}$.

Atlas, R. A., (1993): Handbook of Microbiological Media by Ronald M. Atlas, edited by L. C. Parks CRC Press, Ann Arbor.

American standard for testing material, ASTM- D 280 (1987): Test methods for hygroscopic moisture (and other matter volatile under the test conditions) in pigments.

American standard for testing material, ASTM- D 153 (1989): Standard test method for specific gravity of pigment.

American standard for testing material, ASTM- D 2198 (1989): Standard test method for matter soluble in water.

American standard for testing material, ASTM- D 234 (1991): Standard specification for linseed oil.

American standard for testing material, ASTM- D 281 (1989): Oil absorption of pigments by spatula rub - out.

American standard for testing material, ASTM E 70 (1990): Hydrogen ion concentration "pH value".

Burnet G. James, Mark Flanagan, Donald Peter, Christopher Mackie and Jeffrey Price (2006): calcium carbonate compositions for use in the manufacture of toothpaste; Pub. No US 2006/0275224A1.

Benson, (2001): Microbiological Applications (Laboratory Manual in general microbiology), $8^{\text {th }}$ Ed. McGraw-Hill.

Cowan, S. T., (1993): Cowan and steel's Manual for the Identification of Medical Bacteria. $3^{\text {rd }}$ Ed. Cambridge Univ., Press, London.

Curry, A. S., Joyce, G. G., Joyce, McEwen, G. N. and McEwen, J. r., (1993): CTFA Microbiology guidelines. The Cosmetic, Toiletry, and Fragrance Association, Inc. Washington, D.C.

Gaber, M. A. Wahab (2013): Evaluation of Samalout and Beni Khaled "Minia" limestone for producing paint extender pigment, Inventi rapid: chemical Engineering, Vol. 2013, Issue 1.,1-6

Gutz, H., and Doe F. J., (1973): Two different mating types in Schizosaccharomyces pombe. Genetics, 74, 563-569.

Hucker, G. J., (1927): Further studies on the methods of Gram staining. N. Y. State Agr. Expt. Sta. Tech. Bull. 128.

Harrison, D. J., (1992): Industrial minerals laboratory manual of Limestone, Technical Report WG/92/27, B. G. Survey, $20 \mathrm{p}$.

Indian standard 918(2006): Specification for calcium carbonate, precipitated for cosmetic industry.

Idziak, E. S., and Mossel, D. A. A., (1980): Enumeration of Vital and Thermally Stressed Staphylococcus aureus in Foods Using Baird Parker Pig Plasma Agar (BPP). J. App. Microbiology, 48, 101-113.

Kiruthiga, B., (2011): Dental products report, SRM Institute of Science and Technology (India), department of pharmaceutical chemistry.

Reddy, C., Beveridge, T. J., Breznak, J. A. and Marzluf, G., (2007): Methods for general and molecular microbiology. Amer. Soc. Microbiology Press, 351- 379. 
Gaber, M. A. and Gaber, M. A.

\section{نهج جديد لاستخدام كربونات الكالسيوم المحلية فى صناعة معجون الأسنان

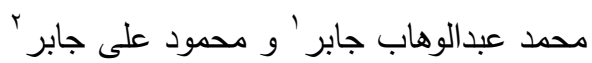 \\ ا معهد بحوث البترول ، قسم الاستكثاف، مدينة نصر ، القاهرة \\ r قشم النبات والميكروبيولوجى ، جامعة الأزهر ، كلية العلوم (بنين) ، القاهرة \\ الخلاصة}

ينم استخدام مادة كربونات الكالسيوم ، في الوقت الحاضر ، على نطاق واسع كمكلات الكالسيوم الغذائية الفعالة، مضادات

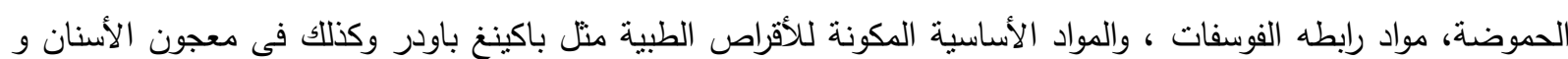
هو موضوع الدراسة .

تقدم هذه الدراسة مساهمة فى توصيف كربونات الكالسيوم الموجودة بكثرة فى منطقه بني خالد بالمنيا لتصنيع المكونات الصيدلانية لمعجون الأسنان الذى يستخدم على نطاق هائل للإنسان.

تم تجميع عينات كربونات الكالسيوم من منطقه الدراسه و كذلك تم طحن هذة العينات الى حبيبات دقيقة جدًا يتراوح حجمها

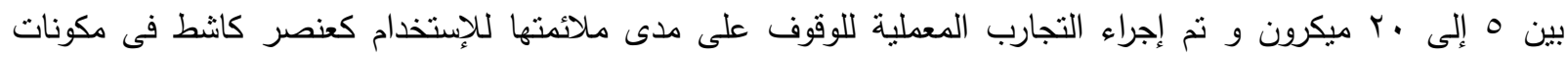

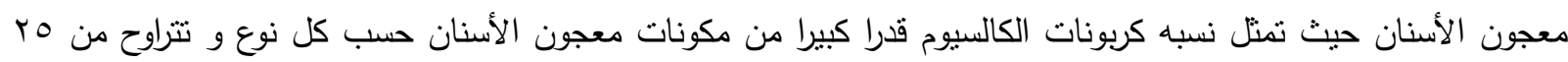

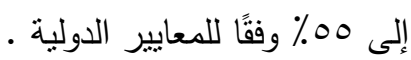

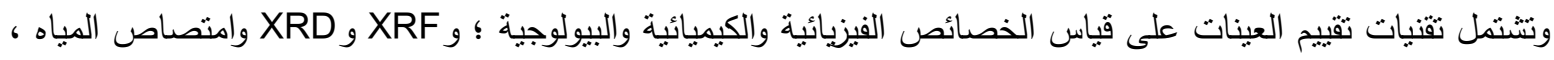

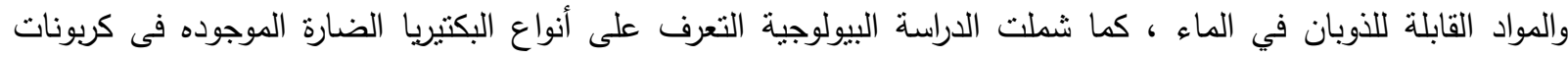
الكالسيوم الطبيعيه . أظهرت النتائج التى نم الحصول عليها للعينات مطابقه الخصائص الفيزيائيه و الكيميائيه لمواصفات كربونات الكالسيوم المستخدمه فى صناعه معجون الأسنان . و قد عالجت الدراسه كيفيه التخلص من هذة البكتريا بتسخين مسحوق CaCO3 حتى اب ا درجة مئوية و تم القياس مرة أخرى ووجد إختفاء جميع أنواع البكتريا وبذلك تسلط الدراسه الضوء على إستخدام جديد لكربونات الكالسيوم المحليه في تصنيع

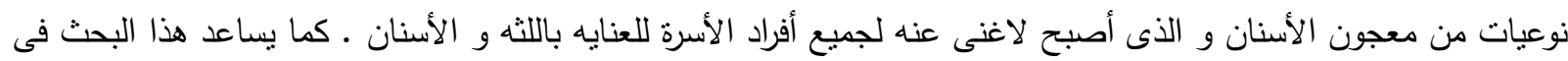

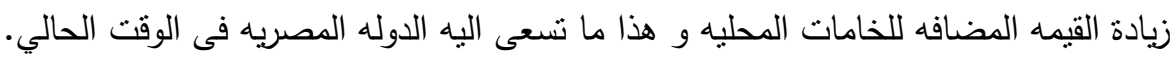

